\title{
XX A. MASINĖS STATYBOS GYVENAMŨJU巳 KOMPLEKSŲ FENOMENAS LIETUVOJE EUROPINIAME INDUSTRINĖS STATYBOS KONTEKSTE
}

\author{
Dalia Dijokiené ${ }^{1}$, Petras Džervus ${ }^{2}$ \\ Vilniaus Gedimino technikos universitetas, Urbanistikos katedra, \\ Pylimo g. 26/Trakug. 1, 01132 Vilnius, Lietuva \\ El.paštas: '1ijokai@takas.lt; ${ }^{2}$ p.dzervus@gmail.com \\ Iteikta 2011-02-15
}

\begin{abstract}
Santrauka. XX a. pradžia pasaulio ir Europos urbanistikos raidoje pasižymi naujo pobūdžio projektavimo ir statybos proveržiu industrinès gyvenamosios statybos fenomenu. Gyvenamieji rajonai, statyti spartiems miestų urbanizacijos procesams reikalaujant didelio kiekio gyvenamųjų būstų, daugelyje Europos miestų paliko žymų pėdsaką. Straipsnyje nagrinèjami masinės statybos gyvenamieji rajonai bei jų atsiradimo aplinkybės (nuo idejų iki realizacijos pasekmių). Paliečiami fenomenui esminès ịtakos turèję nagrinejjamų valstybių politiniai sprendimai, susiję su masinès statybos industrializavimu ir propagavimu. Atliekama lyginamoji analizè, norint išsiaiškinti esminį fenomeno mastą ir ypatumus skirtingose valstybėse. Lietuvos atveju apžvelgiami šešiuose didžiuosiuose miestuose suprojektuoti ir ígyvendinti masinès statybos gyvenamieji kompleksai bei rajonai, nustatoma jų padètis dabartinëje miestų struktūroje, užimama teritorija palyginama su miesto administraciniu plotu bei urbanizuotu miesto plotu.
\end{abstract}

Reikšminiai žodžiai: industrinè statyba, masinè gyvenamoji statyba, gyvenamasis kompleksas, gyvenamasis rajonas, mikrorajonas, urbanistinè struktūra.

\section{Invadas}

XXI a. visi be išimties Lietuvos didieji miestai atsidūrè paradoksaliai keistoje situacijoje, kurią nulèmè ịvairių dèsningumų ir veiksnių visuma. Iš vienos pusės, spartus suburbanizacijos ir stichiškos miestų plètros procesas gali (ir turi) būti siejamas su demokratijos augimu ir ją lemiančios bei lydinčios laisvos ekonominès rinkos plètra. Iš kitos pusės, nudèvètos vidinès miestų teritorijos tampa tos pačios laisvosios rinkos įkaitemis. Tampa akivaizdu, jog Europos urbanistikos chartijoje (Europos... 1993), Aalborgo chartijoje (Charter... 1994), Leipcigo chartijoje (Leipzig... 2007) ir kt. išdesstytų tezių adaptavimas vietinei miestų planavimo sistemai lauktų rezultatų nedavè. Atotrūkis tarp valstybinès urbanistinès politikos (Miestų... 1998) ir jos iggyvendinimo mechanizmų bei galimybių (Tiškus 2007) suformavo atsainų požiūrị i ̣ problemines miestų teritorijas planavimo sistemoje, ypač $\mathfrak{i} X X$ a. masinès statybos gyvenamuosius kompleksus ir rajonus.

Masinès statybos gyvenamieji rajonai yra specifiniai struktūriniai vienetai miestų urbanistiniuose audiniuose savo koncepcija, dydžiu, miesto gyventojų nuošimčiu, populiacijos struktūra, ekonominiu potencialu, nusidèvejimo laipsniu ir daugeliu kitų aspektų. Visoje Rytų ir Centrineje Europoje nuo šių gyvenamųjų struktūrų būklès priklauso didelès dalies miestų populiacijos gyvenimo sąlygos (Miestų... 1998; Valstybinio... 2010). Joms kintant ị blogąją pusę, miestai neišvengiamai susidurs su atsiradusia socialine ìtampa, kuri palaipsniui gali užkirsti kelią ekonominio klimato gerèjimui (Van Kempen et al. 2006). Nors masinès statybos gyvenamųjų rajonų architektūra kritikuota jau nuo XX a. 8-ojo dešimtmečio, Sovietų Sąjungoje egzistavusi totalinè cenzūra suniveliavo architektūrinių detalių mastelio problemas su erdvinès rajonų struktū ros ir socialinès konstrukcijos mastelio problemomis. Šiandien erdvinè masinès statybos gyvenamųjų rajonų struktūra turi ne mažiau problemų nei patys pastatai. Dažnu atveju menkos „modernizmo“" architektūros apraiškos ar pastatų energetinis efektyvumas nèra esminès problemos. Kompleksiniame 
problematikos kontekste kyla poreikis kritiškai ịvertinti struktūrinių industrinès statybos gyvenamųjų kompleksų ir rajonų pokyčių galimybes. Akivaizdu, jog renovacijos objektas turetų tapti nebe pastatas, o visa gyvenamoji aplinka: neidentifikuotos socialinès bendruomenès erdvès, chaotiška žaliųų plotų sistema, neadekvatūs automobilių stovejjimo aikštelių dydžiai ir t. t. (Vyšniūnas et al. 2010).

Straipsnio autoriu įsitikinimu, tokio sudetingo ir kompleksiško uždavinio atspirties taškas privalo būti paties masinès statybos gyvenamųjų kompleksų ir rajonų fenomeno ištakų studija. Straipsnyje keliamas tikslas - XX a. Lietuvoje vykdytos masinès statybos gyvenamujų kompleksų fenomeno masto ir ypatumu palyginamoji analizé europiniame industrinès statybos kontekste. Šia analize siekiama atsakyti ị klausimus: kaip skirtingos politinès sistemos paveikè skirtingą masinès statybos palikimą ir kokie urbanistinès kokybès požymiai būdingi masinès statybos fenomenui. Šis straipsnis yra platesnio tyrimo apie masines statybos gyvenamujų rajonu restruktūrizacijos galimybes ir principus dalis, nubrèžianti gaires tolesniems tyrimams.

Straipsnyje analizuojamas industrinès statybos avangardo valstybių gyvenamųjų rajonų XX a. antrosios pusès fenomeno mastas kapitalistinès ir socialistinès Europos valstybėse. Apžvelgiami politiniai, ekonominių poreikių bei galimybių, idejjiniai ir kiti reikšmingi kontekstai, lemę vienodų idejjų ir analogiškų konceptų virtimą skirtingomis gyvenamosiomis aplinkomis.

\section{Industrinès statybos gyvenamieji kompleksai ir rajonai Europos miestuose}

Masinès statybos gyvenamųjų rajonų galima aptikti visoje Europoje. Tai bendras XX a. reiškinys Europos urbanistikoje. Tačiau kiekviena šalis turèjo savitą šių „XX a. statybų“ scenarijų. Ivairių šalių praktika skyrèsi ne iškeltais socialiniais ar architektūriniais uždaviniais, bet šių uždavinių igyvendinimo mastu ir apimtimi.

Istorinès aplinkybès lèmè, jog pokaryje (1945-1950) pirmaujančia industrinių statybos technologijų šalimi tapo Jungtinè Karalystè. Jau nuo industrinès revoliucijos laikų, kai Jungtinè Karalystè tapo pirmąja (stipriausia) pasaulio ekonomikos šalimi, miestai augo, nes gyventojai sparčiai tapo pramonés darbininkais ir èmè keltis ị miestus.

Kita šalis, tapusi masinès gyvenamosios statybos ikona ir pavyzdžiu, - Švedija. Iš visų Skandinavijos šalių, XX a. kūrusių geroves valstybes, Švedija buvo vienintelè šalis, išlaikiusi neutralitetą Antrajame pasauliniame kare, todèl joje eksperimentai gyvenamosios statybos srityje igavo didžiausią mastą.
Be paminètų Jungtinès Karalystès ir Švedijos, savotiškai masinè industrinè statyba panašiais urbanistiniais principais buvo naudojama daugelyje Europos valstybių. Tačiau ịvairios aplinkybès lèmé, jog nei Prancūzijoje (tai buvo valstybè, kurioje masinès statybos gyvenamųjų rajonų idejja buvo idejja par exelence), nei Suomijoje, nei Vakarų Vokietijoje ši technologija netapo masinè (straipsnyje aptariamas tik Prancūzijos pavyzdys).

\section{Jungtinė Karalystė}

Masinès gyvenamosios statybos minties pradžia galima laikyti XIX a. pabaigos nesèkmingą bandymą chaotišką miestų plètros problemą spręsti ịstatymais (1875 m. Visuomenes sveikatos istatymas) (Вольфензон 1957). Tai lèmé ịvairių idejų, kaip tvarkytis su atsirandančiomis naujomis urbanistinėmis problemomis, iškilimą. Reikšmingas buvo ir E. Hovardo veikalas Miestas-sodas, kuriame autorius ekonominiais skaičiavimais pagrindè koncepcinio apgyvendinimo modelio, talpinančio 58 tūkstančius gyventojų, realumą ir rentabilumą (Вольфензон 1957). Šis modelis siūlè decentralizuotą miesto plètrą, diegtiną industriniais metodais. Buvo bandymai igyvendinti miesto-sodo koncepciją (Letchworth Garden city, Welwyn Garden City). Šis modelis tapo sèkmingai išplètoto Jungtinèje Karalystèje miesto-palydovo prototipu. Tačiau Jungtinejje Karalystëje egzistavusios stiprios individualių ir blokuotų gyvenamųjų namų statybos tradicijos nulèmé, jog XX a. Jungtinejje Karalysteje, naujo tipo miestų plètros ir apgyvendinimo teorijų kalvèje, nauji tipai ir būdai (tokie kaip laisvasis planavimas ir masinè industrializuota statyba) neįsitvirtino ir netapo dominuojantys.

Vienas stipriausių impulsų Jungtinès Karalystès miestuose prasidèti didelio masto naujo tipo gyvenamųjų rajonų projektavimui ir statybai buvo Antrojo pasaulinio karo metu fiziškai sugriauti, sunaikinti rajonai ir ištisos miestų dalys (Бунин, Саваренская 1979). Dar faktiškai karui nepasibaigus prasidejjo gyvenamųjų rajonų rekonstrukcijos projektavimo darbai. $1944 \mathrm{~m}$. Vyriausybė specialiu įstatymu leido savivaldoms išpirkti žemę iš privačiu valdytojų pirmaeiliams uždaviniams igyvendinti. Didiesiems miestams, ypač Londonui, buvo taikomi decentralizuotos plètros principai. Tai lëmè sparčiai didejjantis gyventojų kiekis ir siekis šiuos gyventojus įkurdinti miestuose-palydovuose šalia Londono. Mažesniuose miestuose buvo numatyta pusiau kompaktine plètra, išnaudojant vidinius teritorinius resursus. Tokia plètra leido gyvenamuosius rajonus išdèstyti mieste aplink centrinius rajonus kaip erdvines struktūras, atskirtas žaliosiomis zonomis ir sujungtas transportiniais kanalais. Dèl karo atsiradu- 
sios dykros buvo verčiamos parkais ir skverais - taip mažinamas bendras užstatymo intensyvumas. Naujų gyvenamųjų rajonų statyba perkeliama toliau nuo centrinių rajonų.

Pokaryje prasidejęs miestu-palydovu projektavimas ir statyba neatnešè laukto efekto. Didžiąją dalį šių miestų gyventojų sudarè ne didžiųjų miestų gyventojai, o žmonès iš aplinkinių regionų, kurie kraustèsi arčiau metropoliniu centrų. Visgi miestu-palydovu projektavimo ir statybos būdai įdomūs savo urbanistiniais sprendiniais ir apimtimi. Miestu-palydovu projektavimo nevaržè esamos miestų struktūros, buvo naudojami žymiai laisvesnio planavimo principai. Be geru komunikacijų, kultūrinio ir buitinio aptarnavimo sistemų sukūrimo miestuose buvo siekiama vientisos architektūrinès kompozicijos. Duoklè atiduota ir tradiciniam landšaftiniam miestu planavimo pobūdžiui. Todèl ir naujai projektuojamuose miestuose-palydovuose buvo vengiama tiesiu transporto gatvių, statiškų erdvinių struktūrų.

Pagrindiniai naujų gyvenamųjų rajonų projektavimo principai Jungtinėje Karalystėje iš esmès niekuo nesiskyrè nuo visoje Vakarų Europoje naudotų principų. Mikrorajono tipo erdvinè struktūra, kurios ribos buvo magistralinès miesto gatvès, ir tapo pagrindiniu masinès gyvenamosios statybos Jungtinèje Karalystejje struktūriniu vienetu. Mikrorajonai sudarè stambesnes gyvenamąsias struktūras - gyvenamuosius rajonus. Šiems rajonams buvo būdingi laisvojo planavimo principai. Jungtineje Karalysteje taip pat pastebimas ir kitur nepropaguotas mišraus užstatymo tipo mikrorajonas, kuri galejjo sudaryti ir daugiaaukščiai bokštiniai

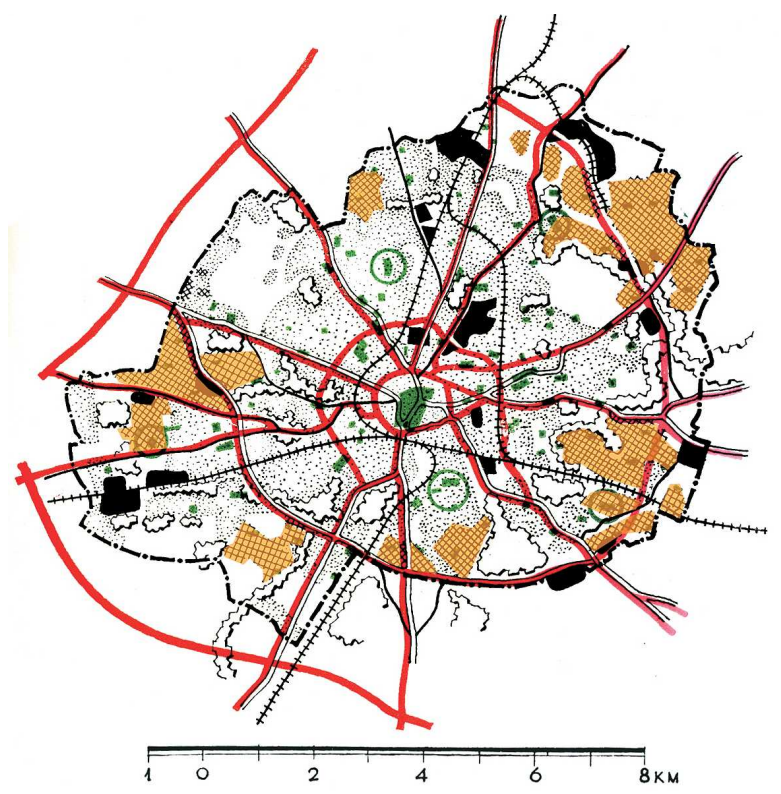

1 pav. Nauju gyvenamuju rajonų išdèstymas, Koventris, Jungtinè Karalystè

Fig. 1. Location of new residential districts in Coventry, UK (angl. tower block), ir daugiabučiai (angl. block of flats), ir studijos tipo daugiabučiai namai (angl. maisonette), ir blokuoti gyvenamieji (angl. row houses), ir netgi privatūs vienbučiai gyvenamieji namai (angl. villas). Projektuojant dažnai būdavo ịvertinami keli užstatymo variantai, naudojant skirtingos tipologijos pastatus (Gendinning, Muthesius 1993).

Jungtineje Karalystėje masinès statybos gyvenamieji rajonai miestuose dažniausia suprojektuoti iš bokštinių ir sekcijinių pastatų. Skirtingų architektų panaudota statinių aukščių ir tipų ịvairovè lèmé, jog Jungtineje Karalystėje išvengta pasikartojančios monotonijos masinès statybos gyvenamųjų rajonų architektūrineje išraiškoje. Visgi planiniuose sprendiniuose naudota laikotarpiui būdinga erdvinè struktūra, ignoruojanti privačių, uždarų erdvių poreikị. Tai labiausiai nulèmė nekokybišką socialinį scenarijų (1, 2 pav.).

\section{Švedija}

Švedija, viena rečiausiai apgyvendintų valstybių Europoje, XX a. tapo viena masinès statybos lyderių. Išskirtini 3 industrine statyba paremtos urbanistines plètros etapai:

1. Apie $1965 \mathrm{~m}$. prasidejęs pavienių gyvenamųjų aukštybinių pastatų ar statinių grupių, kompleksų statybos bumas. Pabrèžtina aukšta statinių projektų ir statybos kokybė, net ir XXI a. pradžioje šie statiniai vis dar populiarūs. Daugiausia ši bumą lèmè valstybės vykdoma gerovés valstybès statybos politika. Šis gyvenamųjų namų statybos etapas ne-

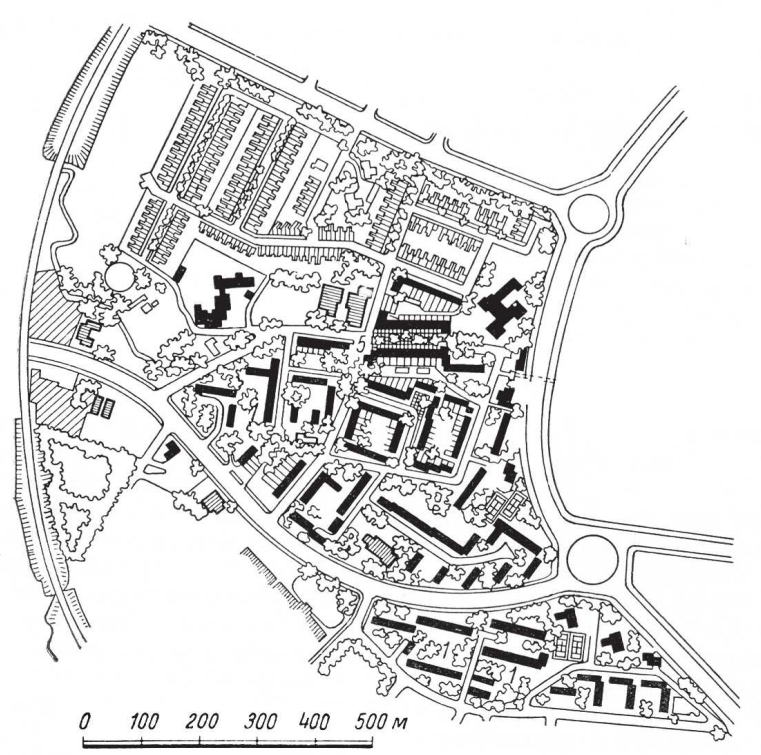

2 pav. Rekonstruojamo gyvenamojo rajono projektas, Koventris, Jungtinè Karalystè

Fig. 2. Plan of a residential district under reconstruction, Coventry, UK 
buvo masinis ir netapo kanoninių užstatymo principų susiformavimo pagrindu.

2. Ištisų miestų rajonų, priemiesčių statybos bumas. Šis etapas skaičiuojamas nuo tada, kai buvo pastatytas Vällingby (vienas žymiausių XX a. suprojektuotų ir pastatytų gyvenamųjų rajonų Švedijoje, tapo prototipu kitiems masinès statybos gyvenamiesiems rajonams, pastatytiems 1965-1974 m.). Šiu rajonu išskirtinumas buvo industriniais metodais paruoštu statybinių dalių masinis naudojimas statyboje. Ištobulinami laisvojo užstatymo principai: linijiniai namai statomi laisvai erdvejje, pagal poreikį pasukant juos 90 laipsnių kampu, paliekant atviras erdves, kuriomis lengvai galima patekti i i šių struktūrų vidines erdves. Tačiau ir šios plano naujovès absoliučiai nepašalino mišraus užstatymo ir aukštingumo tipo bei privačios žemès nuosavybès iš vientiso gyvenamojo rajono.

3. Atskirų pastatų, besiskiriančių aukščiu, funkcija (gyvenamieji namai, viešbučiai, biurai ir t. t.), vieta mieste (centre, centro prieigose, periferijoje) ir nuosavybe (privačios korporacijos, privačių ar valstybinių gyvenamųjų namų statymo kompanijos) statymo etapas. Šiame statybos etape valstybè vykdè tiktai minimalią intervenciją i planavimo procesą (Sweden... 2004).

Naujų statybų "modernumas“ buvo suprantamas kaip senųjų kvartalų nugriovimas ir pakeitimas naujaisiais. Šio scenarijaus igyvendinimo atsakomybe tenka socialdemokratų partijai bei Švedijos architektams ir urbanistams, besižavejjusiems Le Corbusier, W. Gropius'o ir apskritai CIAM’o propaguotomis idèjomis (Sweden... 2004).
Ankstyvaisiais 5-ojo dešimtmečio metais nauju generaliniu planu Stokholmo ateitis pasiūlyta Stokholmo priemiesčiuose naudoti užstatymą, kurio $75 \%$ sudarytų vienbučiai ir blokuoti namai, 10000 žmonių apgyvendinti. Po septynerių metų priemiesčio modelis buvo pakeistas ị 16500 gyventojų turinčią sistemą, kurioje daugiabučiai sudarytų jau $66 \%$ viso užstatymo. Tuomet jau igyvendintame Vällingby tik 10 \% gyvenamųjų pastatų buvo vienbučiai (Sweden... 2004). XX a. viduryje šalies masineje statyboje nusistovi ,švediškasis" gyvenamųjų namų statybos modelis: aukštuminiai gyvenamieji statiniai vidutinio dydžio miestuose ir aukštos kokybės gyvenimo sąlygos.

1965-1974 m. Švedijos vyriausybè vykdè Milijono programa (šved. Miljonprogrammet). Per 10 metų buvo užsibrèžta pastatyti 1 milijoną naujų būstų - 100 tūkstančių kasmet, kiek mažiau akcentuojama tai, jog didele šios programos dalis buvo igyvendinta ir griaunant esančius nemodernizuotus kvartalus netgi miestų centruose. Naujiems gyvenamiesiems rajonams, statomiems igyvendinant programą, etalonu buvo Vällingby ir Årsta gyvenamieji rajonai (3 pav.). Daugelis idejų, pritaikytų šiuose rajonuose, buvo dauginamos. Pagal šią programą daugiau nei 25 miestuose ir jų priemiesčiuose buvo igyvendinti per puse šimto masinès gyvenamosios statybos rajonų projektų (4, 5 pav.).

Apie 8-ąji dešimtmetị Švedijoje ịsivyrauja nauja tendencija - gyventojai statosi privačius namus - vilas. Milijono programos metu igyvendinti gyvenamieji rajonai, nežiūrint pakankamai aukštos erdvinès ir statybinès kokybès, palaipsniui praranda savo patrauklumą (Large... 2003).

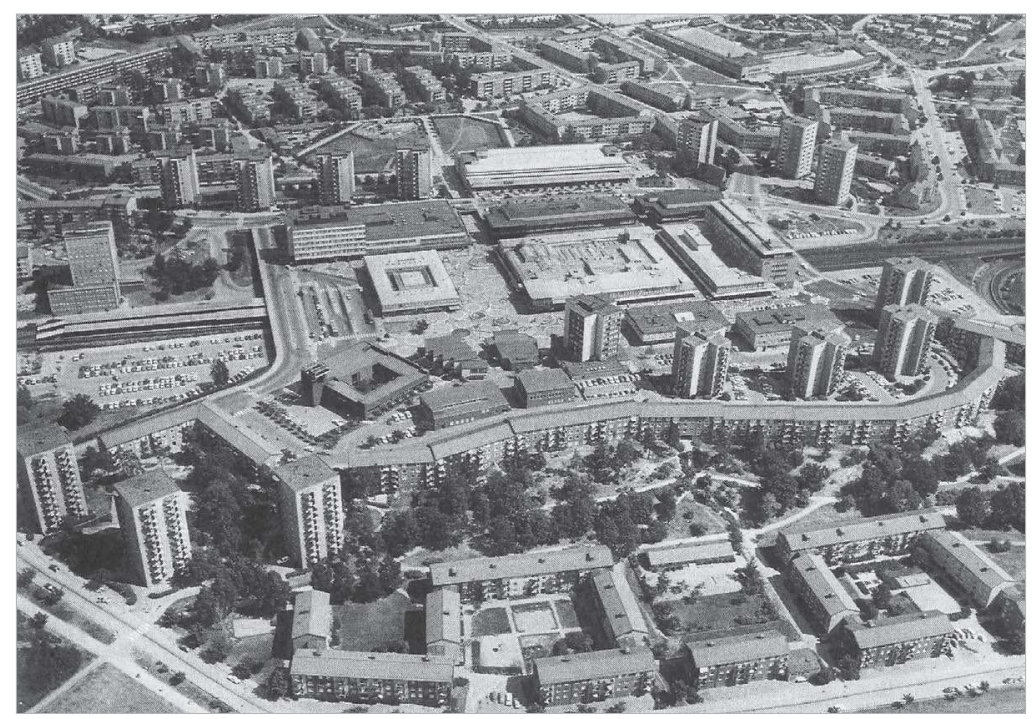

3 pav. Vällingby rajonas $1960 \mathrm{~m}$.

Fig. 3. Vällingby district, 1960 


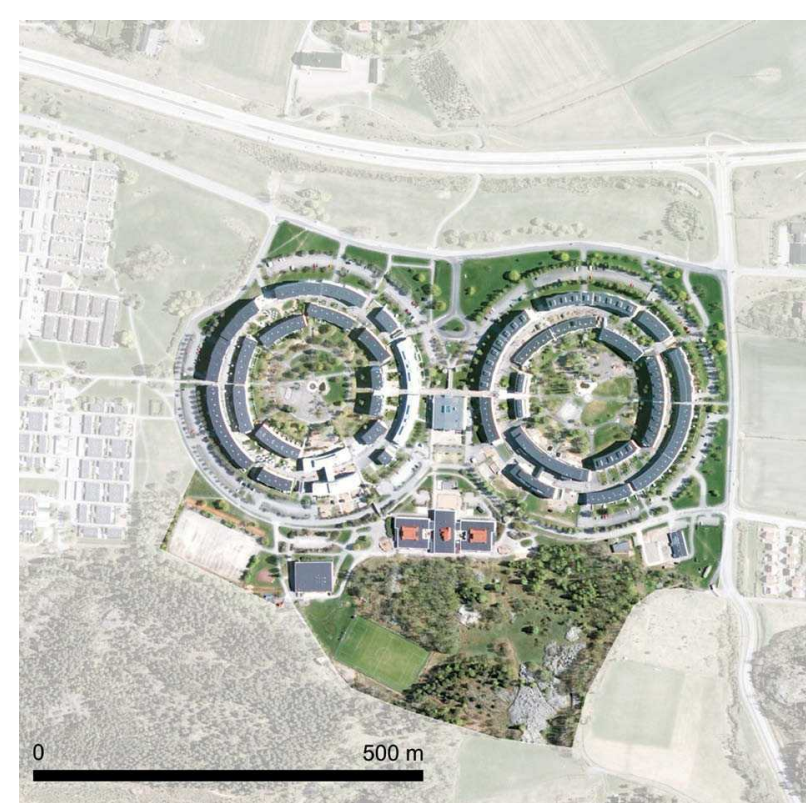

4 pav. Milijono programa. Navestad gyvenamasis rajonas, Norrköping, Švedija

Fig. 4. Million Programme. Navestad residential district, Norrköping, Sweden

\section{Prancūzija}

Prancūzijoje karo apgadintų miestų rekonstrukcijos ir naujų miestų rajonų projektavimui didelę itaką dare Atènu chartijos postulatai (Le Corbusier 1973), jais remiantis būdavo sudaromi masiniai planai (pranc. plans-masse). Tačiau šioje chartijoje deklaruojami urbanistinio projektavimo principai, paremti miesto struktūros skaidymu pagal funkcijas (gyvenimas, darbas, poilsis ir judejiimas tarp jų), negalèjo pateikti aiškių veiksmų algoritmo fragmentiškai karo metu suniokotoms susiklosčiusioms miestų teritorijoms. Gyvenamųjų rajonų statybą taip pat veike ir privati žemès nuosavybè miestų ribose.

Labiausiai nuo karo nukenteję Normandijos miestai (šiaurès Prancūzija) tapo pagrindiniu miestų rekonstrukcijos arealu. XX a. viduryje miestų rekonstrukcijos metu pradejo rastis prieškario ir moderniųjų pokario urbanistinių idejų. Siekiant gyvenamosios statybos rajonų miestuose tobulinimo, suformuojamas „prancūziškasis" gyvenamųjų rajonų struktūrinis vienetas didelis gyvenamasis masyvas habitat (mikrorajonas). Vèliau juos imta vadinti dideliais ansambliais (pranc. grandes ensambles) (Соловьев et al. 1981). Tokie ansambliai-mikrorajonai buvo pastatyti Strasbūre, Mobeže, Marselyje, Bobinji, Pantene. Paprastai tai būdavo naujos, savarankiškos miestų struktūros dalys, kuriamos toliau nuo centrinių rajonų. Specialiai kurtas naujosios architektūros „salelių“ ivvaizdis.

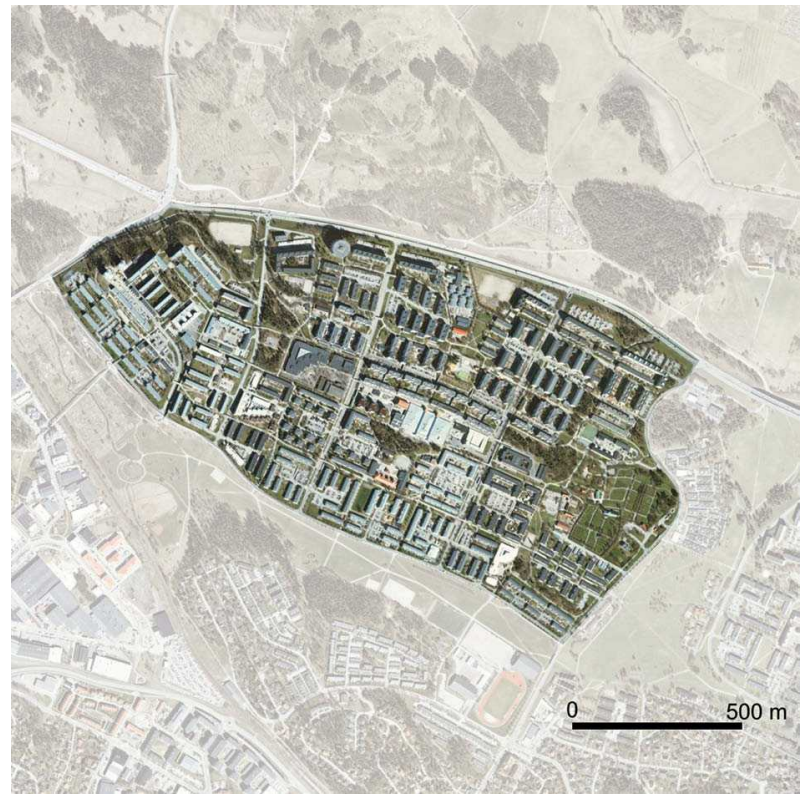

5 pav. Milijono programa. Tensta gyvenamasis rajonas, Stokholmas, Švedija

Fig. 5. The Million Programme. Tensta residential district, Stockholm, Sweden

Dideliuose ansambliuose specialiai buvo naudojami skirtingų tipų, aukščių, tūrių statiniai. Autoriniai architektų projektai, įmantrios erdvinès konstrukcijos lèmè tokių ansamblių vientisumą, o kartu ir išskirtinumą analogų kontekste. Naujuose gyvenamuosiuose kompleksuose architektai tradicinę kiemo erdvę pakeitè vidine kompleksų erdve, kuri tapo tarsi atviru vestibiuliu - pessčiųjų gatvele. Erdvès konstravimo požiūriu toks progresyvus suvokimas leido sukurti nesikartojančių ir patrauklių humaniškų erdvių vidines sistemas, sujungiančias gyvenamojo komplekso pastatus, ir siekiamo komuninio gyvenimo ịvaizdị.

1960-1970 m. Prancūzijos urbanistiniuose sprendiniuose jaučiamos bendros europinès architektūrinès tendencijos, plečiamos miestų struktūros visomis trimis dimensijomis: išnaudojami požemiai; gyvenamuosiuose rajonuose stengiamasi atskirti transporto ir pèsčiųjų lygmenis; kuriamos megastruktūros - pastatai-miestai ir grupès tokių pastatų. Tokioms struktūroms formuoti pasitelkiama industriné statybos pramonè. Tačiau tuo pačiu metu suvokiama, jog gigantiškos urbanistinès struktūros nutolsta nuo humaniško mastelio. Todèl formuojamos „humanizuotos zonos“. Projektuotojai stengiasi sukurti naujo tipo individualizuotus kvartalus, rajonus, naujus miestus. Dėmesys buvo kreipiamas ir ị projektų pasekmes - projektuojant aukštybinių pastatų kompleksus tiriamas jų poveikis miestų siluetams (Соловьев et al. 1981). 
Paryžius, kaip ir daugelis didžiųjų Europos sostinių, XX a. patyrè smarkų demografinị augimą. $1965 \mathrm{~m}$. buvo patvirtinta miesto plètros koncepcija Paryžiaus rajono rekonstrukcijos ir plètros generaliné schema. Pasirinktas decentralizuojantis aglomeracija plètros modelis. Miestai-palydovai kuriami tęsiant urbanistines ašis dvieju pobūdžiu kryptimis. Buvo numatyti penki nauji miestai: šalies šiaureje Sergy Pontoise ir Marn la Valle bei pietuose - Melun, Evry, Saint Quentin en Yvelines. Buvo numatoma, jog XX a. pabaigoje šie penki miestai-palydovai turès po 300-500 tūkstančius gyventojų.

Besiplečiančiose Paryžiaus ribose, priemiesčiuose kuriami nauji gyvenamieji rajonai, naudojama industrializuota statybos pramonè. Dauguma šių rajonu tampa manieringomis erdvinèmis struktūromis, integraliomis miesto urbanistinès struktūros dalimis. Aukštas meninis šių urbanistinių kompleksų lygis, masiškas progresyvių idèjų naudojimas ir igyvendinimas (tokių kaip pagrindinių erdvių kanalo sukons- travimas kuriant pėsčiųjų esplanadas) padarè šiuos rajonus (Defance, Créteil) sunkiai identifikuojamus kaip masinès statybos produkciją (Соловьев 1979). Juolab kad juos formuojant, didelę reikšmę turèjo ir nuostata apie monofunkcio rajono neatitikti "modernaus" gyvenimo reikmèms.

Nuo XX a. vidurio Prancūzijoje suformuojamos šalies miestu plètros nuostatos. Jos turejo kelis principinius punktus: kiekybinis poreikis, statybos industrializavimas, „atvirojo tipo“ urbanizacija (Соловьев et al. 1981). Remiantis šiomis nuostatomis didieji ansambliai buvo pastatyti Lilyje, Lione, Marselyje, Tūre, Strasbūre, Bordo ir kituose miestuose. Šiuos ansamblius vienija erdvinio karkaso konstravimo principai bei industriniais metodais gamintos surenkamos, monolitinès statybinès detalès. Tačiau visų šių rajonų individualumas neleidžia jų suniveliuoti iki bendro vardiklio, kuris $\mathrm{XXI}$ a. de facto lemia neigiamą požiūrị ị tokius masinès gyvenamosios statybos rajonus (6, 7 pav.).

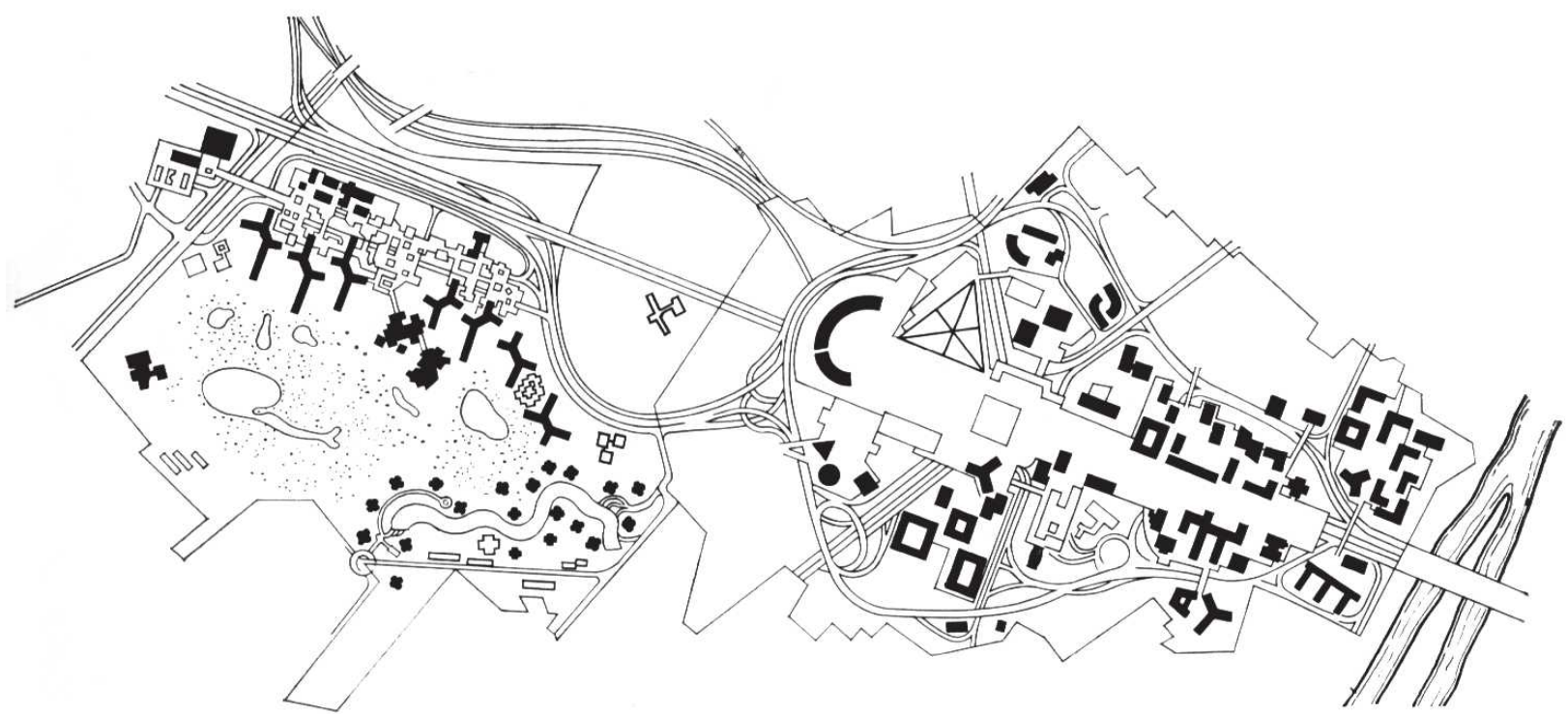

6 pav. Defance rajonas Paryžiuje, Prancūzija

Fig. 6. Defance district in Paris, France

7 pav. Defance rajono Paryžiuje aksonometrija, Prancūzija

Fig. 7. Axonometry of Defance district in Paris, France

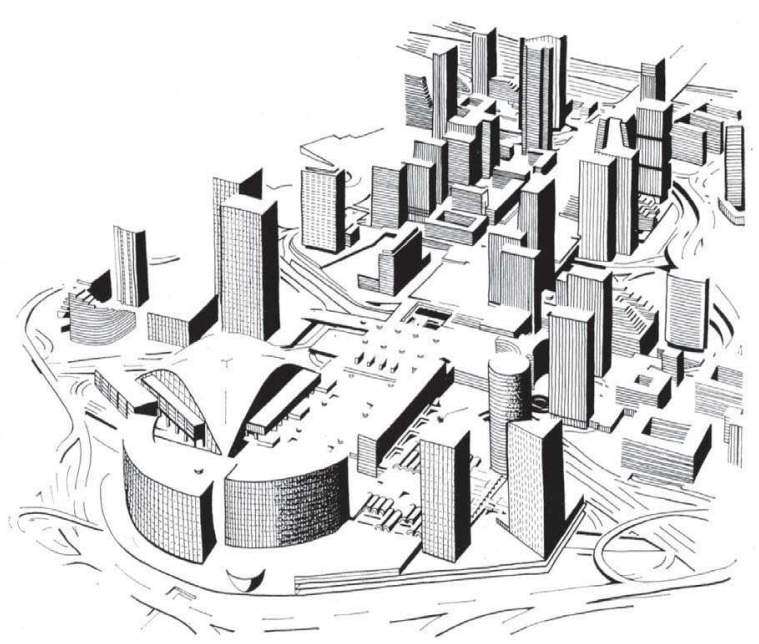




\section{Industrinès statybos}

\section{gyvenamųjų rajonų formavimo principai ir aplinkybès Sovietų Sąjungoje}

Sovietų Sąjungoje idejjiniame masinio apgyvendinimo koncepcijų lygmenyje rungési urbanizacijos ir disurbanizacijos idejos. Abiejų suburbanizacijos (suburbanizacija - urbanistinių funkcijų sklidimas ị priemiesčius) stovyklų idejjoms nebuvo lemta būti ịgyvendintoms. Eksperimentavimą nutraukè Stalino valdymo laikotarpis - šalis neįtikètinu mastu militarizavosi, tam išnaudodama visus finansinius resursus ir gamtinius išteklius. Tik XX a. 6 dešimtmetyje naujajam Sovietų Sąjungos lyderiui N. Chruščiovui panaikinus stalinistinio režimo suvaržymus Maskvos universiteto intelektualų grupè, vadovaujama Aleksèjaus Gutnovo, tęsè prieškaryje sustabdytus idejjinius eksperimentus ir išleido veikalą Idealus komunistinis miestas (Scott 2009). Teoriniame lygmenyje, ieškant Sovietų Sąjungos urbanistinių masinès statybos gyvenamųjų rajonų bei naujų augančio miesto dalių koncepcijų, buvo eksperimentuojama miesto-sodo (angl. garden city), linijinio miesto (angl. linear city), superkomuny (angl. supercommune), mobiliu ateities miestu (angl. mobile cities of the future) modeliais.

Sovietų Sąjungoje išplitęs gyvenamasis kompleksas (mikrorajonas) buvo konstruojamas pagal tam tikrą logiką, kurioje atsispindèjo kai kurie urbanizacijos bei disurbanizacijos idejų šalininkų siūlymai. Tiesa, panaudoti sprendimai nebuvo išvystyti taip radikaliai, kaip siūlè minètos teorijos. Be to, Sovietų Sąjungos ekonominis potencialas niekada nesugebejo patenkinti milžiniškos šalies urbanizacijos poreikių.

1950 m. Sovietų Sąjungos CK iškèlus gyvenamųjų namų gamybos industrializavimo ir masinio taikymo statyboje ideją, prasidejo aktyvus tinkamų modelių ieškojimo periodas. XX a. viduryje pagrindinis mènesinis architektūros reikalų žurnalas publikavo daug straipsnių, nagrinèjančių ịvairius klausimus, susijusius su masine daugiabučiu statyba, keletas jų: Svarbūs tipinio projektavimo uždaviniai [Важные задачи типового проектирования] (Остапенко 1954); Tipiniu projektu gamyba serijiniu būdu [O применении типовых проектов и составе их серий] (Кравчук 1973); Tіріпіu gyvenатuјu патu architektūros pagerinimo büdai [Пути улучшения архитектуры типовых жилых домов] (Зальцман 1954) ir kiti. Atmetus ideologini straipsnių patosą, pastebimas aiškus siekis ịgyvendinti socialistinès valdžios įsakymą - sukurti naujos statybines metodikos pagrindus nuo urbanistinio (miesto) lygmens iki industriniais büdais gaminamu pastatu detalių. Didelis dèmesys skirtas užsienio patirčių gyvenamosios statybos analizei (Гроссман 1958; Михайлов 1963; Соловьев 1979; Соловьев et al. 1981; Зальцман 1954).
Planinė ekonomika ir žemės nuosavybės nebuvimas tapo palankia terpe įsivyrauti vientisai miestų urbanistinès plètros koncepcijai, nežiūrint ị milžinišką šalies plotą, demografinius, kultūrinius ir gamtinius regioninius skirtumus. Politinis diktatas, primetęs socialistinès visuomenès modelio kūrimą, ir tikrojo ekonominio pajègumo santykis su deklaruojamuoju tapo esminiais dalykais, dèl kurių XX a. viduryje sukurtas progresyvus gyvenamųjų rajonų (ir apskritai miestų plètros) projektavimo ir statybos modelis, teorineje plotmejje atrodęs ittikinamas ir kokybiškas, realybeje virto apgailètinos architektūrinès ir socialinès (arba bendrai - urbanistinès) kokybės gyvenamąja terpe (Grava 1993). Galiausia XX a. 9-ajame dešimtmetyje subyrëjus Sovietinei imperijai, atkūrus žemès nuosavybès santykiais grịstą urbanistinę sistemą, pasirodè, jog socialistiniais laisvojo planavimo principais paremti masinès statybos gyvenamieji rajonai turi labai miglotas galimybes išlikti tokie, kokie jie buvo suprojektuoti (Kosareva, Struyk 1993).

\section{Industrinè gyvenamoji statyba Lietuvos miestuose}

Nuo XX a. 6-ojo dešimtmečio vidurio Lietuvos miestų plètrą reguliavo 1954-1955 m. sovietinès vyriausybès nutarimai Dèl priemoniu projektavimui gerinti, statybai industrializuoti ir nesaikingumams šalinti bei 1957 m. liepos 31 d. nutarimas Dél gyvenamuju namu statybos išvystymo Tarybu Sajungoje (Drèmaitè 2006).

Daug reikšmès XX a. industrializuotos statybos užmojams iggyvendinti Lietuvoje turëjo prof. K. Šešelgio (kartu su bendradarbiais) 1958-1960 m. parengta Vieninga apgyvendinimo sistema. Šis regioninio planavimo lygmens dokumentas lèmé gana tolygų Lietuvos miestų industrializavimą, o kartu ir jị lydintị tolygų gyventojų skaičiaus miestuose augimą bei naujų gyvenamųjų rajonų statybą.

Naujų gyvenamųjų rajonų projektavimas Lietuvoje, kaip ir kitose socialistinio bloko šalyse, vyko pagal tą patị modelị. Neegzistuojant privačiai žemès nuosavybei, negalejo egzistuoti nevalstybinè projektavimo sistema. Gyvenamosios statybos planavimo srityje vyravo direktyvinis valdymo modelis: centrinè sąjungos valdžia nustatydavo bendrus prioritetus ir ūkio vystymo kryptis. Lokalioji valdžia besąlygiškai juos vykdydavo, adaptuodama lokalioms sąlygoms. Lietuvoje (kaip ir kitose sovietinèse respublikose) buvo sukurti miestų statybos ir projektavimo institutai, kuriuose buvo intensyviai projektuojami kartotiniai, masinei statybai pritaikyti pastatai ir surenkami jų elementai, taip pat rengiami gyvenamųjų rajonų planų bei schemų, mikrorajonų ir atskirų kvartalų-pastatų kompleksų planai (LTSR... 1967, 1971). 
Gyvenamųjų rajonų vietos būdavo nurodomos miestų generaliniuose planuose. Statybos racionalizavimas ir masinis analogiškų statybinių modulių naudojimas lèmé, jog masinèms statyboms parinktos vietos, darant kai kurias išimtis, pasižymėdavo ypač neišraiškingu reljefu. Taip siekta maksimaliai supaprastinti statybos procesą, unifikuoti statybos metodus, išvengti sudètingu situacijų tiesiant gatves ir t. t. Pačių rajonu projektavimo principai paremti atstumu iki buitinès priežiūros ir socialinès infrastruktūros objektų išlaikymu, maksimalaus numatyto užstatymo tankio ir intensyvumo siekiamybe, griežtų sanitarinių ir higieninių normų laikymusi. Architektų saviraišką stabdè ne tik pastatų tipų unifikacija, buvo susiduriama su menka architektūrine įvairove ir skurdžiomis urbanistinių elementų tarpusavio jungimosi galimybėmis.

"Socialistinei visuomenei“ kurti buvo svarbios naujos erdvès formos. Urbanistiniai kompleksai negalejo formuoti uždarų kiemų erdvių, kurios galèjo priminti tam tikrus privačios erdvès, privataus gyvenimo atributus. Laisvojo planavimo principais suformuotuose gyvenamuosiuose rajonuose siektas maksimalus užstatymo intensyvumas virto gigantiškų chaotiškų erdvinių sistemų ịrankiu. Pasiekta teigiama naujų gyvenamųjų kompleksų socialinè reikšmè neatstojo neigiamo estetinio poveikio (Miškinis 1991).

7-ajame XX a. dešimtmetyje rengtuose miestų generaliniuose planuose atsirado naujų tendencijų, buvo visiškai atsisakoma miesto plètros, paremtos kompaktiškumo principais. Ėmè aiškèti tendencija formuoti savitus individualios struktūros miestus. Tačiau tik keli masinès statybos gyvenamieji rajonai buvo Lietuvos urbanistikos tyrinètojų ịvertinti palankiai - tai Žirmūnai ir Lazdynai Vilniuje bei Kalniečiai Kaune (Miškinis 1991; Vanagas 2003). Kiti didžiųjų ir vidutinio dydžio miestų gyvenamieji rajonai nesusilaukè tokio įvertinimo. A. Miškinis apie kompleksinę gyvenamųjų rajonų statybą rašè: „Atrodytų, kad einant šiuo keliu, galètų būti sèkmingai išvengiama monotonijos ir miestų naujųjų dalių supanašèjimo. Tačiau kol kas yra kitaip. <...> kartu su gerai ịvertintais gyvenamaisiais kompleksais buvo statoma ir nemaža gana pilkų bei nepakankamai raiškių, panašių ir monotoniškų" (Miškinis 1991).

Masinès statybos gyvenamųjų rajonų, mikrorajonų, gyvenamųjų kompleksų ir kvartalų yra visuose Lietuvos miestuose. Ju projektavimo metodika ir statybos būdai niekuo nesiskyrè nuo didesniuose miestuose igyvendintų analogiškų projektų, išskyrus tai, jog projektuose būdavo atsižvelgiama ị demografinius miestų, miestelių ir miestelio tipo gyvenviečių ypatumus. Savotiškai individualūs masinès gyvenamosios statybos projektai buvo igyvendinti Lietuvos kurortuose Nidoje ir Birštone. Tačiau šie keli (paviršutiniškai unikalūs) atvejai nesudaro jokio pagrindo ịžvelgti kontekstualumo paieškų projektuojant ar tuo labiau statant masinès statybos gyvenamuosius rajonus. Straipsnyje pateikiamos šešių didžiųjų Lietuvos miestų teritorijų administracinių ribų schemos su pažymètais industrinès gyvenamosios statybos kompleksais ir rajonais (8 pav.). Šių urbanistinių struktūrų užimamos teritorijos palyginimas su miesto administraciniu plotu bei urbanizuotu plotu išryškina reiškinio mastą (žr. lentelę).

Lietuvoje gyvenamųjų rajonų projektavimo sektoriuje dirbusių architektų ir urbanistų saviraiška buvo maksimaliai suvaržyta statybų pramonès poreikių, paremtų politinèmis direktyvomis, tenkinimu. Vietiniai projektuotojai galejo naudotis labai ribotais gaminių katalogais. Architektūrinès ir urbanistinès variacijos buvo suvaržytos griežtais higieninių normatyvų reikalavimais, transporto infrastruktūros tipiniais sprendiniais ir kt. Vakarų Europos šalyse XX a. moderniąją statybą akivaizdžiai lydi gyvenamosios aplinkos gerinimas - naujų erdvių tipų paieškos (pèsčiųjų esplanados, vidinès kvartalų erdvès, gamtinès aplinkos naudojimas). Taip pat beveik kiekvienu atveju Vakarų Europoje pastatų kompleksas buvo individualus auto-

Lentelè. Industrinès gyvenamosios statybos mastas Lietuvos miestuose

Table. Scale of industrialized construction in Lithuanian cities and towns

\begin{tabular}{lcccc}
\hline Miestas & $\begin{array}{c}\text { Administracinis } \\
\text { plotas }\left(\mathbf{k m}^{2}\right)\end{array}$ & $\begin{array}{c}\text { Urbanizuotos teritorijos } \\
\text { plotas }\left(\mathbf{k m}^{2}\right)(\% \text { viso ploto) }\end{array}$ & $\begin{array}{c}\text { Masines statybos plotas } \\
\left(\mathbf{k m}^{2}\right)\end{array}$ & $\begin{array}{c}\text { Centrinis miesto rajonas } \\
\left(\mathbf{k m}^{2}\right)\end{array}$ \\
\hline Vilnius & 401 & $130(32,4 \%)$ & $20,9(16,1 \%)$ & 7,94 \\
\hline Kaunas & 157 & $83,5(53,2 \%)$ & $11,9(14,2 \%)$ & 2,52 \\
\hline Klaipèda & 98 & $36,3(37,1 \%)$ & $8,4(23,2 \%)$ & 2,83 \\
\hline Šiauliai & 81 & $40,8(50,4 \%)$ & $3,9(9,5 \%)$ & 2,59 \\
\hline Panevèžys & 52 & $27,2(52,4 \%)$ & $3,9(14,4 \%)$ & 2,05 \\
\hline Alytus & 48 & $15,6(32,5 \%)$ & $2,8(17,7 \%)$ & 0,65 \\
\hline
\end{tabular}




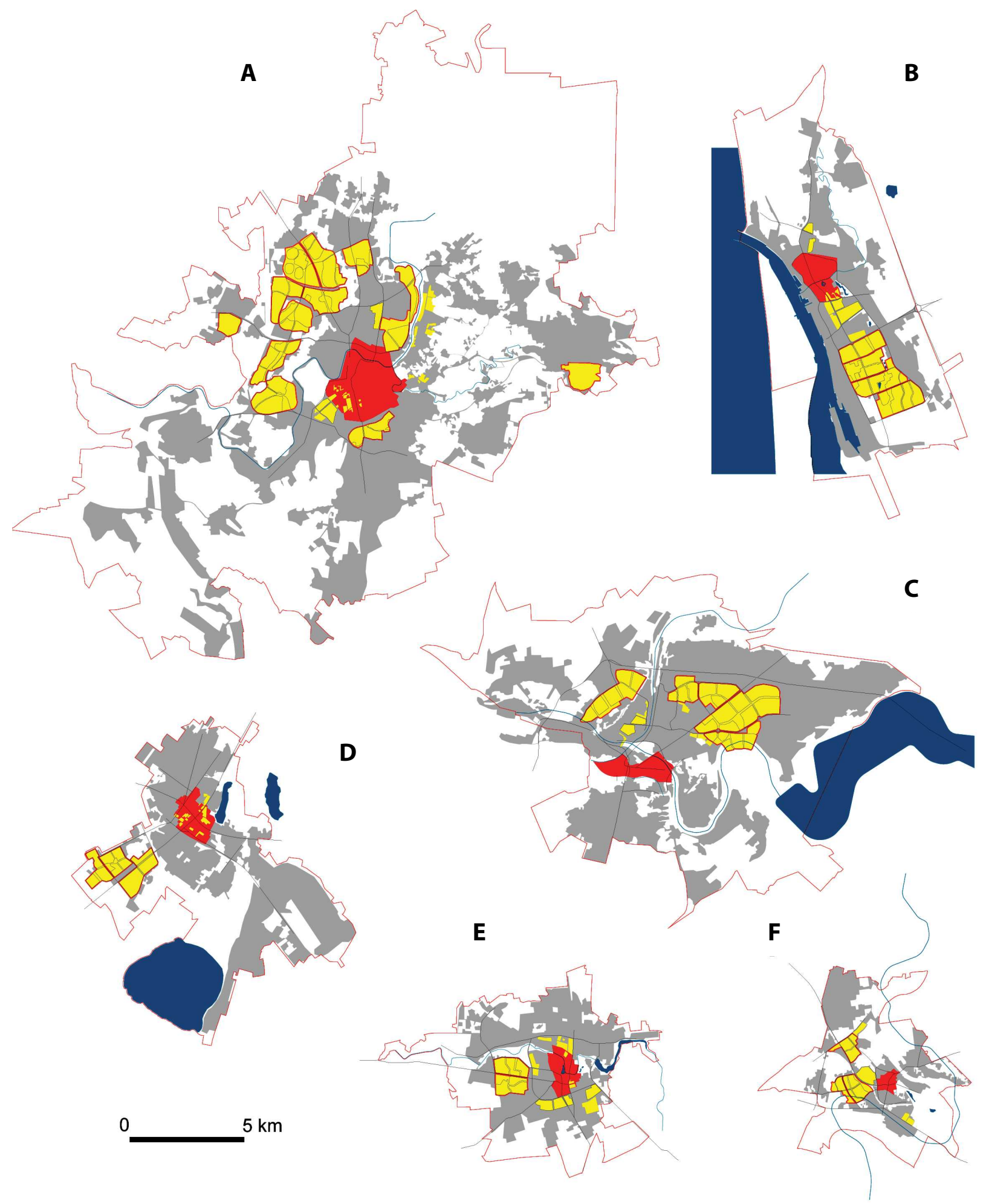

EKSPLIKACIJA

8 pav. Industrinės statybos gyvenamieji kompleksai ir rajonai Vilniuje (A), Klaipėdoje (B), Kaune (C), Šiauliuose (D), Panevėžyje (E), Alytuje (F)

Fig. 8. Residential complexes and districts of industrialized construction in Vilnius (A), Klaipèda (B), Kaunas (C), Šiauliai (D), Panevėžys (E) and Alytus (F) 
rinis architektų kūrinys. Šie kompleksai nesiniveliuoja tarpusavyje, nesudaro kritinès masės gyvenamosiose miestų dalyse. Nors kaip ir Sovietų Sąjungoje buvo siekiama naujos kokybės higieninių sąlygų, vykdomos socialinès apgyvendinimo programos.

Priklausomybé Sovietinei imperijai lèmé, jog Lietuvoje, projektuojant masinès statybos gyvenamuosius rajonus, optimizavimas ir racionalizavimas tapo svarbiausiais uždaviniais. Galutinis rezultatas būdavo toks, kad atsirasdavo statybiniu technologijų kokybès, projektų igyvendinimo kompleksiškumo ir gyvenamosios aplinkos gerovés sutvarkymo akivaizdžių skirtumų.

Šiandien masinès statybos gyvenamųjų rajonų būklè yra sudètingai pamatuojama. Priklausomai nuo galimos analizès aspekto ir nagrinejjamo $(-u$ ) konteksto $(-u)$ galima gauti labai nevienareikšmius rodiklius. Ir nors masinès statybos gyvenamieji rajonai užima nedidelę dabartinių miestų administracinių ribų teritorijų dali ( 4-7 \%), tai visiškai neatspindi Lietuvos miestų urbanistinių ir socialinių aktualijų bei problemų masto pasiskirstymo miestuose: masinès statybos gyvenamuosiuose rajonuose gyvena apie $60 \%$ visų miestų gyventojų (Bardauskienè 2007), o didžiuosiuose miestuose šis procentas siekia 80 \% (Valstybinio... 2010).

\section{Išvados}

1. Nors įvairių Europos valstybių XX a. industrializuotos masinès statybos gyvenamųjų kompleksų ir rajonų koncepcinis pamatas yra kaimynystes vieneto ir miesto-sodo idejja, fizinès, ekonominès ir socialinès šių struktūrų aplinkos skirtumai šiandien akivaizdūs. Skirtumus nulemę ekonominiai ir demografiniai kontekstai tapo vykdytos politikos pasekmemis. Vakarų Europoje masinès gyvenamosios statybos aktualumas neatskiriamas nuo demokratinių valstybių valdymo modelių, kuriuose didelị vaidmenį atliko laisvosios rinkos ekonomika, jos ciklai, gyventojų mobilumas, industrijos vystymasis ir virsmas i globalios rinkos poreikius atitinkančią gamybą, aiškūs žemès nuosavybès santykiai. Visa tai turèjo įtakos demokratiškose valstybèse vykdytoms lanksčioms socialinèms programoms, kurių viena iš svarbiausių dalių - gyventojus aprūpinti socialiniu būstu. Besikeičiantys visuomeniniai poreikiai eliminavo aprūpinimo būstu įrankị - surenkamąją statybą - kaip nebeatitinkančią laikotarpio poreikių, sunkiai pertvarkomą ir nerentabilią koncepciją. Socialistiniame bloke vykdyta visa apimanti socialistinès santvarkos statybos politika eliminavo laisvosios rinkos elementus, žemès nuosavybę, susiklosčiusias socialines struktūras. Sukurta nauja gyvenamoji aplinka - laisvo plana- vimo masinès statybos gyvenamasis kompleksas tapo vieninteliu i̇manomu gyvenimo konceptu, iš esmès nepakitusiu pusę amžiaus, niekaip nereaguojančiu ị pasaulinès ekonomikos ciklus, visuomeninius poreikius, pramonès pokyčius ir t. t. Dar daugiau - gyvenamuosiuose rajonuose norma tapo poreikių neatitinkantys faktiniai sprendiniai, prasta statybinè kokybe், nesaugi ir nehumaniška aplinka.

2. Urbanistinė kokybė paprastai matuojama pagal erdvinio karkaso ir užstatymo morfologijos aiškumą, funkcinę atitiktị socialiniams poreikiams, visumos darną ir susisiekimo sistemos efektyvumą. Masinès statybos gyvenamųjų rajonų, ypač Rytų Europoje, erdvinè, morfologinès, funkcinès ir socialinès struktūros kokybė yra labai prasta. Tai reiškia, jog struktūrinès permainos, keičiantis visuomeniniams poreikiams, yra neišvengiamos. Vadinasi, vidinèse miestų teritorijose esančių urbanistinių struktūrų, kurių pagrindiniai identifikacijos požymiai yra kompleksiškumas ir baigtumas, kokybè identifikuotina pagal urbanistinès struktūros kitimo galimybių lygi, bet ne pagal subjektyviai nustatomus rodiklius, tokius kaip tariama meniné kokybė: architektūrinės formos, spalviniai pastatų fasadų sprendimai, atskiri dekoro elementai ir kiti, su erdvine bei socialine rajono struktūra nieko bendro neturintys aspektai.

3. Lietuvoje gyvenamoji statyba XX a. antrojoje pusėje tapo masiniu reiškiniu. Šis fenomenas paliko ryškų ir nevienareikšmį pèdsaką Lietuvos miestų struktūrose. Esminę reikšmę masinès statybos gyvenamųjų rajonų kokybei (ypač lyginant su Vakarų Europa) Lietuvoje turëjo deklaruojamų tikslų ir realių projektavimo bei statybos sąlygų ir galimybių neatitikimas. Industrinės statybos gyvenamieji rajonai kelia daug restruktūrizavimo galimybių klausimų, yra akivaizdžiai ardomi erdvinès mutacijos procesų, tačiau vis dar nèra pagrindinių urbanistinių analizių epicentre. Tą rodo absoliutus masinès statybos gyvenamųjų rajonų restruktūrizavimo koncepcijų ignoravimas miestų planavimo lygmenyse. Šių kompleksų problematikos identifikavimą ir koncepcinių modelių sukūrimą apsunkina dirbtinai padidinamos administracinès rajonų ribos, naujas perkomponavimas sujungiant su svetimomis šiems rajonams urbanistinemis struktūromis.

4. Lietuvos miestuose per 20 nepriklausomybès metu insivyravusi dispersinè pletra, vangiai reguliuojamas spartus priemiesčių augimas, miestų kaip monocentrinių struktūrų stiprèjimas iš esmès aplenkẻ masinès statybos gyvenamuosius rajonus. Šie ra- 
jonai daugelyje atvejų iš miestų paribių tapo neintegraliomis miestų vidinių struktūrų dalimis. Šios dalys buvo apeitos sprendžiant būtino miesto struktūrinio atsinaujinimo ir būsto fondo didinimo klausimus. Palaipsniui šios miestų dalys virsta labiausiai nudèvètomis teritorijomis, turinčiomis sudètingiausius galimos rekonstrukcijos scenarijus. Kelių masinès statybos gyvenamujų rajonu ivvertinimas aukštais buvusios Sovietų Sajungos apdovanojimais ir Lietuvos urbanistikos tyrinètojų pripažinimas, jog šiuose gyvenamuosiuose rajonuose galima aptikti tik Vakarų Europoje igyvendintų masinès statybos urbanistinių sprendinių , ,atgarsius“, parodo tikrąją šių Lietuvos miestų dalių kokybę. Ji kai kuriais atvejais pranašesnè nei Sovietų Sąjungoje masiškai įvykdytų analogišku projektų, tačiau nè iš tolo neprilygo Vakarų Europoje pasiektai kokybei.

\section{Literatūra}

Bardauskienè, D. 2007. Miesto bendrasis planas ir ekspertiniai vertinimai, Urbanistika ir architektūra [Town Planning and Architecture] 31(3): 119-130.

Charter of European Cities \& Towns Towards Sustainability. 1994. Aalborg [interaktyvus], [žiūrèta 2011-02-02]. Prieiga per internetą: <http://sustainable-cities.eu/upload/pdf_files/ac_english.pdf $>$.Large Housing Estates in Sweden. Overview of developments and problems in Jönköping and Stockholm. 2003. Andersson, R.; Molina, I. (Eds.). Utrecht: Utrecht University. 120 p.

Drèmaitè, M. 2006. Pigiau, daugiau, greičiau. Masinè gyvenamoji statyba ir modernizavimo kanonai, Naujasis židinys - Aidai, 8: 321-328.

Europos urbanistikos chartija. 1993. Strasbūras: Europos taryba. $112 \mathrm{p}$.

Gendinning, M.; Muthesius, S. 1993. TOWER BLOCK: Modern Public Housing in England, Scotland, Wales and Northern Ireland. London: Yale University Press. 420 p.

Grava, S. 1993. The Urban Heritage of Soviet Regime The Case of Riga, Latvia, Journal of the American Planning Association 59: 1, 9-30. doi:10.1080/01944369308975842

Kosareva, N.; Struyk, R. 1993. Housing Privatization in the Russian Federation, Housing Policy Debate 4(1): 81-100.

Large Housing Estates in Sweden. Overview of developments and problems in Jönköping and Stockholm. 2003. Andersson, R.; Molina, I. (Eds.). Utrecht: Utrecht University. $120 \mathrm{p}$.

Le Corbusier. 1973. The Athens Charter. New York: Grossman.

LEIPZIG CHARTER on Sustainable European Cities. 2007. Leipzig [interaktyvus], [žiūrèta 2011-02-02]. Prieiga per internetą: <http://www.eu2007.de/en/News/download_ docs/Mai/0524-AN/075DokumentLeipzigCharta.pdf>.

LTSR MT Valstybinis statybos reikalų komitetas, Miestų statybos projektavimo institutas, Respublikinis skyrius. 1967. Lietuvos TSR miestu kvartalų ir mikrorajonu išplanavimo-užstatymo projektu rinkinys. Vilnius.
LTSR MT Valstybinis statybos reikalų komitetas, Miestų statybos projektavimo institutas, Respublikinis I skyrius. 1971. Lietuvos TSR miestų kvartaly ir mikrorajony išplanavimo ir užstatymo projektų rinkinys. II tomas, 1967-1971 m. projektai. Vilnius.

Miestu atnaujinimo ir gyvenamojo fondo modernizavimo politikos igyvendinimo strategijos. 1998. Lietuvos Respublikos aplinkos ministerija, Europos ekonominè komisija. Vilnius. $47 \mathrm{p}$.

Miškinis, A. 1991. Lietuvos urbanistika: istorija, dabartis, ateitis. Vilnius: Mintis.

Scott, S. W. M. 2009. The ideal soviet suburb: social change trough urban design, in Panorama [interaktyvus], [žiūrèta $2010 \mathrm{~m}$. gruodžio 2 d.]. Prieiga per internetą: $<$ http://www.design.upenn.edu/files/Panorama09_14_ SovietSuburb_Scott.pdf $>$.

Sweden: High-rise housing for a low-density country. 2004. Turkington, R.; van Kempen, R. and Wassenberg, E. (Eds.). High-rise housing in Europe: current trends and future prospects Delft: Delft University press (Housing and Urban Policy Studies 28), 31-48.

Tiškus, G. 2007. Urbanistines plètros valstybinio valdymo problemos: I Urbanistinio forumo pranešimų rinkinys. Vilnius.

Vanagas, J. 2003. Miesto teorija. Vilnius: VDA leidykla.

Van Kempen, R.; Murie, A.; Knorr-Siedow, T.; Tosic, I. 2006. Regenerating large housing estates in Europe: A guide to better practice. Utrecht: Utrecht University.

Valstybinio audito ataskaita. Daugiabučiu namų atnaujinimas (modernizavimas). 2010. Lietuvos Respublikos Valstybès kontrolè. $49 \mathrm{p}$.

Vyšniūnas, A.; Džervus, P.; Cirtautas, M. 2010. Gyvenamuju rajony ir pastatu renovacijos metodiniu principu ir kriteriju sistema. Problemos sprendimo algoritmas. Aplinkos atnaujinimo programa. UAML Oficialus atsakymas/pasiūlymas LAR ir LAS.

Бунин, А.; Саваренская, Т. 1979. Градостроительство ХХ века в странах капиталистического мира. II том. Москва: Стройиздат.

Вольфензон, Е. 1957. Вопросы планировки и застройки городов за рубежом. Москва: Гос. изд-во лит. по строителъству и архитектуре.

Гроссман, В. 1958. Городские жилые дома в Швеции. Москва: Гос. изд-во лит. по строительству, архитектуре и строительным материалам.

Зальцман, А. 1954. Пути улучшения архитектуры типовых жилых домов, Архитектура СССР 8: 6-9.

Кравчук, Я. Т. 1973.Формирование новых городов. Москва: Стройиздат. $112 \mathrm{c}$.

Михайлов, Б. (Ред.). 1963. Всеобщая история архитектуры. Москва: Гос. изд-во лит. по строительству, архитектуре и строительным материалам.

Остапенко, М. А. 1954. Важные задачи типового проектирования, Архитектура СССР 8: 1-2.

Соловьев, Н.; Турчин.; В.; Фирснов, В. 1981. Современная архитектура Франции. Москва: Стройиздат. 303 с.

Соловьев, Н. 1979. Дефанс - новый квартал Парижа, Архитектура СССР 2: 41-45. 


\section{THE 20TH CENTURY PHENOMENON OF LARGE- SCALE CONSTRUCTION OF RESIDENTIAL AREAS IN LITHUANIA WITHIN THE CONTEXT OF EUROPEAN INDUSTRIALIZED CONSTRUCTION}

\section{Dijokienè, P. Džervus}

Abstract. At the beginning of the 20th century, urban development in Europe and worldwide was marked by a breakthrough of a new phenomenon in the field of planning and construction - the industrialized housing construction. Residential districts that were constructed in order to meet a massive housing demand determined by intensive urbanization processes have left a significant mark in many European cities. The article analyses residential districts of large-scale construction and circumstances that determined formation of this phenomenon (from ideas to consequences of their implementation). Attention is drawn to crucial political decisions taken by the countries concerned relating to industrialization and promotion of large-scale constructions. A comparative analysis is carried out with a view to determining the scale and characteristics of this phenomenon in various countries. In case of Lithuania, residential complexes and districts of large-scale construction built in six major cities of the country are reviewed, including analysis of their position in the current urban structure, comparison of the size of their territories with that of the towns' administrative and urbanized areas.

Keywords: industrialized construction, large-scale construction of residential areas, residential complex, residential district, micro district, urban structure.

\section{DALIA DIJOKIENE்}

Doctor of the Humanities (architecture), Assoc.Prof., Dept of Urban Design, Vilnius Gediminas Technical University, Pylimo g. 26/Traku g. 1, 01132 Vilnius, Lithuania. E-mail:dijokai@takas.lt.

Research interests: urban nuances of town spatial expansion beyond the old town's borders. Conferences: reports at 5 international and 6 national conferences. Teaching: lectures of architectural and urban design. Projects: author or co-author of more than 30 projects of architectural design and planning.

\section{PETRAS DŽERVUS}

PhD student, assistant, Dept of Urban Design, Vilnius Gediminas Technical University, Pylimo g. 26/Traku g. 1, 01132 Vilnius, Lithuania. E-mail: p.dzervus@gmail.com.

Research interests: urbanism, spatial layout structure of towns and districts, renovation of living and public space in urban structures. Projects: author or co-author of master plans and detailed plans, individual housing design. 